\title{
Perbedaan Hasil Keterampilan Proses Sains Melalui Model Pembelajaran Inquiry dan Model Pembelajaran Inquiry dengan Metode Pictorial Riddle bagi Siswa SMP Negeri 1 Gunungsari Tahun Ajaran 2015/2016
}

\author{
Yunita ${ }^{1}$, Muhammad Zulfikar Syuaib ${ }^{2}$, Muhammad Taufik ${ }^{2}$ \\ ${ }^{1)}$ Program Studi Pendidikan fisika \\ ${ }^{2)}$ Program Studi Pendidikan Fisika FKIP \\ Universitas Mataram \\ Mataram, Indonesia \\ Email: yunita.cute93@gmail.com
}

\begin{abstract}
The experimental research is aimed to revealing the difference between science process through inquiry learning model and inquiry learning model with pictorial riddle method for students in SMP Negeri 1 Gunungsari academic year 2015/2016. The research designs is using pretest posttest control group design. The samples were chosen by purposive sampling technique. The population is all students of SMP Negeri 1 Gunungsari grade VIII, while the samples are the students in VIII D class (experiment class 1) and VIII F class (experiment class 2). The instrument of this research is the science process skills test in form of reasoned multiple choice, which has been tested statistically it's validity, reliability, discrimination index and level of difficulty of the item. The data analysed used independent sample t-test at significant level $\alpha$ of $5 \%$ with $t_{\text {count }}$ is 2,535 and $t_{\text {table }}$ is 1,671 because $t_{\text {coun }}>t_{\text {table, }}$, then $H_{0}$ is rejected and $H_{a}$ accepted. The result indicates that there is a difference between science process through inquiry learning model and inquiry learning model with pictorial riddle method for student in SMP Negeri 1 Gunungsari academic year 2015/2016.
\end{abstract}

Keywords: Inquiry Learning Model, Pictorial Riddle, Science Process Skills

\section{PENDAHULUAN}

Pada hakekatnya, IPA merupakan salah satu cabang ilmu pengetahuan yang terus mengalami perkembangan setiap tahunnya seiring dengan perkembangannya itu, masalah-masalah dalam pembelajaran IPA khususnya fisika mulai dicari solusinya. Pembelajaran fisika akan lebih menarik apabila guru menyajikan pembelajaran yang sesuai dengan tuntutan kurikulum pendidikan. Salah satu tuntutan kurikulum pendidikan adalah mampu melaksanakan kegiatan pembelajaran yang melibatkan peran aktif para siswa.

Berdasarkan hasil observasi yang dilakukan peneliti selama melaksanakan Praktik Pengalaman Lapangan (PPL) di SMP Negeri 1 Gunungsari didapatkan bahwa aspek sikap dan keterampilan sudah dilaksanakan dalam proses pembelajaran. Akan tetapi, pada aspek keterampilan, guru masih belum melakukan pelatihan dan penilaian keterampilan proses sains secara spesifik. Pengembangan keterampilan proses sains siswa masih belum tersusun secara sistematis dan dalam proses pembelajaran guru belum memfokuskan pembelajaran pada keterampilan proses sains. Apabila kegiatan pembelajaran terus dilakukan seperti ini, mengakibatkan siswa kurang terlatih untuk mengembangkan daya berfikirnya dalam proses pembelajaran.

Salah satu alternatif yang digunakan untuk memecahkan masalah dalam meningkatkan keterampilan proses sains adalah dengan menggunakan model pembelajaran inquiry, dalam kegiatan pembelajaran inquiry ini siswa dilatih untuk meningkatkan keterampilan proses seperti menggunakan alat, mengumpulkan data, menerapkan konsep, berkomunikasi, menarik kesimpulan.

Model inquiry merupakan strategi pembelajaran yang merangsang, mengajarkan dan mengajak siswa untuk berpikir kritis, analitis dan sistematis dalam rangkan menemukan jawaban 
secara mandiri dari berbagai permasalahan yang diutarakan [1]. Tujuan umum dari model pembelajaran inquiry adalah untuk membantu siswa mengembangkan keterampilan intelektual dan keterampilan - keterampilan lainnya seperti mengajukan pertanyaan dan mencari jawaban. Metode pictorial riddle merupakan suatu proses pembelajaran yang menggunakan teka teki gambar sebagai media dalam pembelajaran guna untuk membangkitkan motivasi dan minat siswa dalam diskusi kelompok baik kelompok kecil maupun besar. Alasan peneliti dalam pembelajaran fisika menggunakan metode pictorial riddle ini karena dalam pembelajaran fisika sendiri tidak terlepas dari gambar yang dapat memberikan siswa untuk mudah memahami pelajaran dan menangkap materi yang disampaikan oleh guru. Sebab tanpa gambar siswa terlihat kesulitan menerima pelajaran terutama dalam menganalisis yang berkaitan dengan keterampilan.

Berdasarkan permasalahan di atas, tujuan penelitian ini adalah untuk mengetahui perbedaan hasil keterampilan proses sains melalui model pembelajaran inquiry dan model pembelajaran inquiry dengan metode pictorial riddle pada siswa SMP Negeri 1 Gunungsari Tahun Ajaran 2015/2016. Hasil penelitian ini diharapkan bermanfaat bagi pengembangan kegiatan pembelajaran dalam pelajaran fisika untuk melatih keterampilan proses sains fisika dan dapat bermanfaat bagi guru, siswa, sekolah serta bagi peneliti yang ingin mengambil kajian yang sama guna meningkatkan keterampilan proses sains fisika siswa.

\section{METODE PENELITIAN}

Penelitian ini termasuk penelitian eksperimen yang merupakan metode penelitian yang digunakan untuk mencari pengaruh perlakuan tertentu terhadap yang lain dalam kondisi yang terkendalikan [2]. Penelitian ini dilaksanakan mulai bulan Juli 2015 sampai dengan Oktober 2015, bertempat di SMP Negeri 1 Gunungsari. Pada penelitian ini ada tiga variabel yang menjadi fokus penelitian yaitu variabel bebas yang merupakan variabel yang menjadi sebab timbulnya variabel dependen variabel bebas pada penelitian ini adalah pembelajaran inquiry dengan metode pictorial riddle untuk kelas eksperimen 1 dan pembelajaran inquiry untuk kelas eksperimen 2, variabel terikat merupakan variabel yang menjadi akibat adanya variabel bebas. variabel terikat adalah keterampilan proses sains fisika siswa, dan variabel kontrol adalah materi, tujuan pembelajaran, instrumen, alokasi waktu dan cara penilaian. Desain penelitian menggunakan pretestposttest control group design yang bertujuan untuk memperoleh perbedaan keterampilan proses sains fisika siswa antara kelas eksperimen 1 dan kelas eksperimen 2, sehingga pada akhirnya akan mendapatkan perbedaaan dari model pembelajaran yang digunakan. Secara bagan, desain penelitian ini digambarkan pada Tabel 1:

Tabel 1. Desain Penelitian

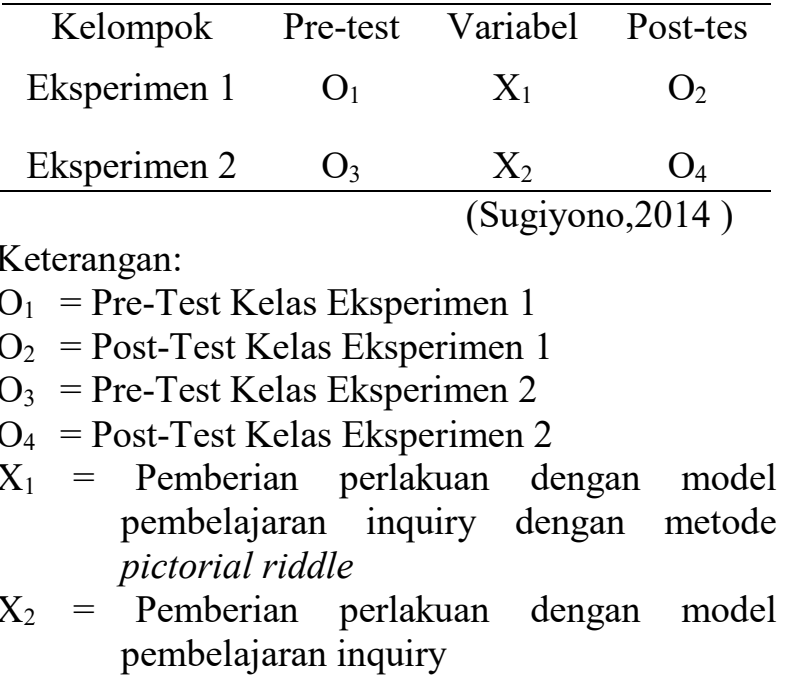

Adapun teknik pengambilan sampel yang digunakan adalah purpsive sampling yang merupakan sampel yang diambil oleh peneliti apabila peneliti memiliki alasan-alasan tertentu berkenaan dengan sampel yang akan diambil. Sampel hasil yang didapatkan adalah kelas VIII D sebagai kelas eksperimen 1 dengan jumlah 32 orang dan kelas VIII F sebagai kelas eksperimen 2 dengan jumlah 33 orang Prosedur kegiatan penelitan ini dilakukan dalam tiga tahap, yaitu:

\section{Tahap Persiapan}

Pada tahap persiapan, peneliti mempersiapkan segala sesuatu yang dibutuhkan pada saat penelitian, di antaranya: (1) Melakukan observasi di sekolah terkait kegiatan belajar mengajar di SMP Negeri 1 Gunungsari; (2) Menentukan sampel penelitian; (3) Menentukan materi pokok yang akan diajarkan dengan pembelajaran inquiry dengan metode pictorial riddle ; (4) Membuat instrumen penelitian, berupa silabus, RPP, LKS, kisi-kisi soal dan tes 
keterampilan proses sains; (5) Memvalidasi instrumen dengan validasi ahli; (6) Menguji coba instrumen untuk menguji validitas dan reliabilitas instrumen, serta analisis butir soal; (7) Menganalisis hasil uji coba instrumen.

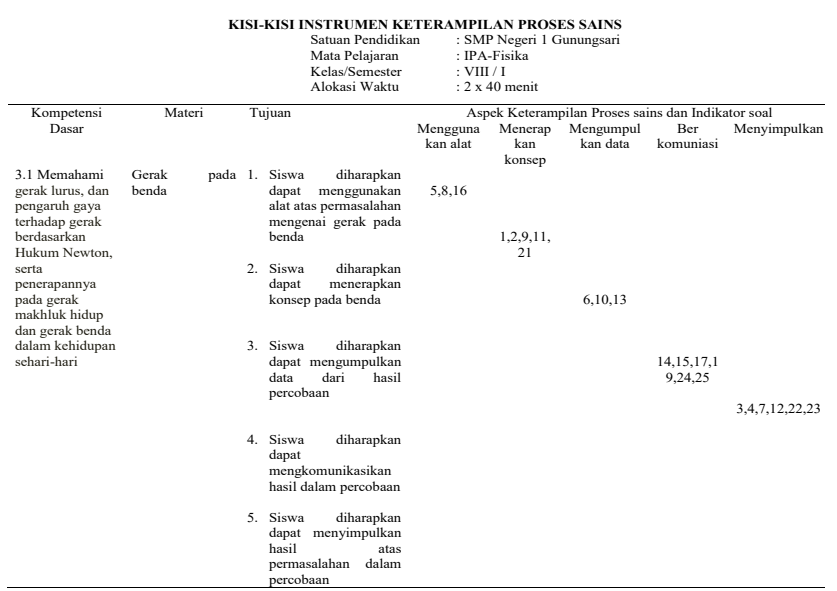

Tahap Pelaksanaan

Adapun langkah-langkah yang ditempuh pada saat pelaksanaan penelitian, yakni: (1) Memberikan pretest kepada kedua kelompok sampel; (2) Memberikan perlakuan berupa pembelajaran inquiry dengan metode pictorial riddle untuk kelas eksperimen 1 dan berupa pembelajaran inquiry unruk kelas eksperimen 2 di sekolah; (3) Memberikan posttest kepada kedua kelompok sampel.

\section{Tahap Akhir}

Pada tahap akhir ini dilakukan analisis data penelitian, menyimpulkan data penelitian, dan membuat laporan hasil penelitian.Teknik pengumpulan data dilakukan dengan metode tes menggunakan tes keterampilan proses sains. Data keterampilan proses sains merupakan data pretest sebelum diberikan perlakuan dan data posttest setelah perlakuan. Data pretest dan posttest diperoleh menggunakan instrument yang telah diujicobakan kepada 35 siswa kelas IX E yang sudah menerima materi gerak pada benda sebelumnya, kemudian hasil tes tersebut dianalisis dengan uji validitas, realibilitas, tingkat kesukaran dan daya beda soal. Analisis validitas soal menggunakan rumus product moment dan untuk uji realibilitas soal menggunakan rumus Spearman-Brown, indeks kesukaran soal untuk tingkat kesukaran soal dan indeks diskriminasi untuk daya beda soal. Analisis data menggunakan menggunakan statistik parametrik t-test polled varians dengan kriteria uji satu pihak, yang sebelumnya telah diuji normalitas data menggunakan uji Chi Kuadrat dan homogenitas data menggunakan uji F. Berdasarkan hasil penelitian untuk uji validitas soal yang digunakan yaitu sebanyak 25 soal dengan menentukan kategori item soal sesuai dengan kriteria yang ditetapkan yaitu jika $r_{x y} \geq r_{\text {tabel }}$, maka item dikatakan valid, dan jika $r_{x y}<r_{\text {tabel }}$, maka item dikatakan tidak valid.

\section{HASIL DAN PEMBAHASAN}

\section{Hasil Penelitian}

Hasil penelitian berupa deskripsi data keterampilan proses sains siswa dari pretest dan posttest dengan menggunakan uji homogenitas, uji normalitas dan uji hipotesis ( $t$-test polled varians dengan kriteria uji satu pihak). Adapun data hasil pretest posttest keterampilan proses sains pada kelas eksperimen 1 dan kelas eksperimen 2 pada materi gerak pada benda dapat dilihat pada Tabel 2 berikut ini:

Tabel 2. Hasil Uji Homogenitas Pretest

\begin{tabular}{cccccc}
\hline Kelas & $\begin{array}{c}\text { Jumlah } \\
\text { Sampel }\end{array}$ & Varians & $\mathrm{F}_{\text {hitung }}$ & $\mathrm{F}_{\text {tabel }}$ & Kesimpulan \\
$\begin{array}{c}\text { Eksperimen } \\
1\end{array}$ & 32 & 55,8 & & & \\
& & & & & \\
$\begin{array}{c}\text { Eksperimen } \\
2\end{array}$ & 33 & 82,2 & & & \\
\hline
\end{tabular}

Tabel 2 menunjukkan hasil uji homogenitas varians kedua kelas. Kelas eksperimen 1 dengan jumlah sampel 32 siswa, variansnya adalah 55,8, sedangkan kelas eksperimrn 2 dengan jumlah sampel 33 siswa, variansnya 82,2 dan hasil perhitungan uji homogenitas untuk kedua kelas tersebut yakni untuk $F_{\text {hitung }} 1,47$ dan $F_{\text {tabel }} 1,81$ $(1,47<1,81)$, sehingga dapat disimpulkan bahwa kedua sampel tersebut homogen atau siswa kelas eksperimen 1 dan kelas eksperimen 2 memiliki kemampuan awal yang sama. 
Tabel 3 Hasil Data Postest Pada Kedua Kelas

\begin{tabular}{lcc}
\hline Komponen & $\begin{array}{c}\text { Kelas } \\
\text { Eksperimen 1 }\end{array}$ & $\begin{array}{c}\text { Kelas } \\
\text { Eksperimen 2 }\end{array}$ \\
\hline Jumlah Siswa & 32 & 33 \\
Nilai & 80 & 77 \\
Tertinggi & 41 & 34 \\
Nilai & 59,18 & 51,7 \\
Terendah & 13,22 & 10,48 \\
Rata-Rata & Normal & Normal \\
Standar & \multicolumn{2}{c}{ Homogen } \\
$\begin{array}{l}\text { Deviasi (SD) } \\
\text { Uji } \\
\text { Normalitas }\end{array}$ & \multicolumn{2}{c}{ dan $\mathrm{H}_{\mathrm{a}}$ diterima } \\
Uji \\
Homogenitas
\end{tabular}

Dalam Tabel 3. di atas terlihat bahwa ratarata nilai kelas eksperimen 1 setelah posttest juga lebih tinggi dari pada kelas eksperimen 2, yaitu rata-rata nilai kelas ekperimen 59,18 dan rata-rata nilai kelas eksperimen 2 yaitu 51,7. Berdasarkan hasil posttest, kelas eksperimen 1 maupun kelas eksperimen 2 mengalami peningkatan, yang menunjukkan terjadinya peningkatan keterampilan proses sains siswa. Hasil di atas menunjukkan bahwa peningkatan nilai rata-rata yang dialami kelas eksperimen 1 lebih tinggi daripada peningkatan nilai rata-rata kelas eksperimen 2 .

\section{Pembahasan}

Dalam pembahasan ini yang dijelaskan adalah hasil análisis data yang diambil dari kelas eksperimen 1 dan kelas eksperimen 2 yakni data hasil pretest dan postest. Setelah mengikuti proses pembelajaran pada materi gerak pada benda, siswa diberikan tes akhir (postest) berupa tes keterampilan proses sains. Adapun nilai rata-rata yang diperoleh kelompok siswa yang mengikuti proses pembelajaran menggunakan model pembelajaran inquiry dengan metode pictorial riddle (eksperimen 1) sebesar 59,2, sedangkan pada kelompok siswa yang mengikuti proses pembelajaran dengan model pembelajaran inquiry nilai rata-ratanya sebesar 51,7 , berdasarkan nilai rata-rata kedua kelas tersebut dapat dilihat bahwa nilai rata-rata kelas eksperimen 1 lebih besar dibandingkan dengan kelas eksperimen 2 sehingga terdapat perbedaan antara kedua kelas eksperimen 1 dan kelas eksperimen 2 .
Selanjutnya berdasarkan hasil uji normalitas dan uji homogenitas data postest, didapatkan bahwa kelas eksperimen 1 dan kelas eksperimen 2 normal dan homogen dengan nilai $\mathrm{T}_{\text {hitung }}=1,76$ dan $\mathrm{T}_{\text {tabel }}=1,81$. Setelah data dianalisis uji statistik berupa uji-t menggunakan SPSS 17, diperoleh $\mathrm{t}_{\text {hitung }}=5,58$ dan $\mathrm{t}_{\text {tabel }}=2,53$ sehingga $\mathrm{H}_{\mathrm{o}}$ ditolak dan $\mathrm{H}_{\mathrm{a}}$ diterima. Hal ini menunjukkan bahwa pembelajaran dengan menggunakan model pembelajaran inquiry dengan metode pictorial riddle memiliki ketrampilan proses sains yang jauh lebih baik daripada siswa yang belajar menggunakan model pembelajaran inquiry saja tanpa metode pictorial riddle. Dengan kata lain, dari hasil analisis yang dilakukan dan deskripsi yang diberikan bisa dikatakan bahwa ada perbedaan hasil keterampilan proses sains melalui model pembelajaran inquiry dan model pembelajaran inquiry dengan metode pictorial riddle bagi siswa SMP Negeri 1 Gunungsari tahun ajaran 2015/2016 .

Penelitian ini didukung oleh penelitian yang telah dilakukan sebelumnya yaitu oleh Marliasani (2013) menyatakan bahwa adanya perbedaan hasil keterampilan proses sains siswa melalui model pembelajaran inquiry dengan metode pictorial riddle. Hasil penelitian ini sekaligus menguatkan penelitian-penelitian mengenai model pembelajaran inquiry yang telah dilakukan sebelumnya. Namun, berbeda dengan penelitian sebelumnya, dalam penelitian ini model pembelajaran inquiry dipadukan dengan metode pictorial riddle dalam melatih keterampilan proses sains siswa.

\section{PENUTUP}

Berdasarkan análisis data, pengujian hipótesis, yang telah dilakukan, peneliti dapat menyimpulkan bahwa terdapat perbedaaan hasil keterampilan proses sains melalui model pembelajaran inquirí dan model pembelajaran inquiry dengan metode pictorial riddle bagi siswa SMPN 1 Gunungsari tahun ajaran 2015/2016. Hasil keterampilan proses sains lebih tinggi menggunakan model pembelajaran inquiry dengan metode pictorial riddle dibandingkan tanpa menggunakan metode pictorial riddle dengan model yang sama. Diharapkan adanya penelitian lanjutan tentang model pembelajaran inkuiri dengan metode-metode yang disesuaikan dengan 
materi pembelajaran, sehingga bisa didapatkan data yang lebih akurat.

\section{REFRENSI}

[1] Ahmadi, K dan Amri, S. 2010. Proses Pembelajaran Inovatif dan Kreatif dalam Kelas. Jakarta : PT Prestasi Pustakarya

[2] Arikunto, S. 2012. Dasar-Dasar Evaluasi Pendidikan. Jakarta: Bumi Aksara.

[3] Dewi, S. 2011. Pengaruh Pendekatan Keterampilan Proses Sains Terhadap Keterampilan Proses Sains Siswa Pada Konsep Suhu dan Kalor. Artikel Penelitian Universitas Islam Negeri syariah Hidayatullah

[4] Hartono, R. 2014. Ragam Model Pembelajaran yang Mudah Diterima Murid. Yogyakarta: DIVA Press.

[5] Marlinasari, D. 2013 Pengaruh Penerapan Metode Inkuiri Dengan Pendekatan Media Pictorial Riddle Terhadap Hasil Belajar Siswa Dalam Pembelajaran IPA. Artikel Penelitian Universitas Tanjungpura Pontianak.

[6] Rusman. 2011. Model-Model Pembelajaran: Mengembangkan Profesionalisme Guru. Jakarta: PT Raja Grafindo Persada.

[7] Rustaman, N.Y. 2007. Keterampilan Proses Sains. Bandung: UPI.

[8] Sanjaya, W. 2006. Strategi Pembelajaran Berorientasi Standar Proses Pendidikan. Jakarta: Kencana.

\section{BIOGRAFI PENULIS}

Yunita, Lahir di Karang Kemong, Mataram, Tanggal 28 Juni 1993. Penulis menyelesaikan bangku pendidikan SD, SMP, dan MA di Mataram. Kemudian, melanjutkan studinya di Universitas'Mataram pada FKIP mengambil Program Studi Pendidikan Fisika dan Lulus pada tahun 2016. 